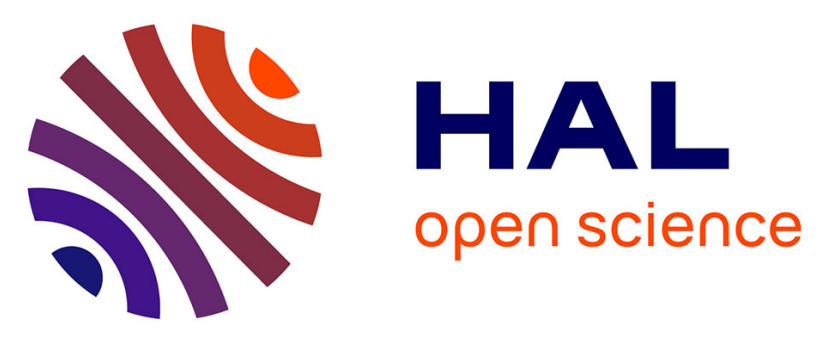

\title{
Wheat gluten, a bio-polymer to monitor carbon dioxide in food packaging: Electric and dielectric characterization
}

Jean Clency Fabien Bibi, Carole Guillaume, Nathalie Gontard, Brice Sorli

\section{- To cite this version:}

Jean Clency Fabien Bibi, Carole Guillaume, Nathalie Gontard, Brice Sorli. Wheat gluten, a biopolymer to monitor carbon dioxide in food packaging: Electric and dielectric characterization. Sensors and Actuators B: Chemical, 2017, 250, pp.76-84. 10.1016/j.snb.2017.03.164 . hal-01606496

\section{HAL Id: hal-01606496 \\ https://hal.science/hal-01606496}

Submitted on 26 May 2020

HAL is a multi-disciplinary open access archive for the deposit and dissemination of scientific research documents, whether they are published or not. The documents may come from teaching and research institutions in France or abroad, or from public or private research centers.
L'archive ouverte pluridisciplinaire HAL, est destinée au dépôt et à la diffusion de documents scientifiques de niveau recherche, publiés ou non, émanant des établissements d'enseignement et de recherche français ou étrangers, des laboratoires publics ou privés.

\section{다(1)(2)}

Distributed under a Creative Commons Attribution - ShareAlikel 4.0 International 


\section{Accepted Manuscript}

Title: Wheat gluten, a bio-polymer to monitor carbon dioxide in food packaging: Electric and dielectric characterization

Authors: Fabien Bibi, Carole Guillaume, Nathalie Gontard, Brice Sorli

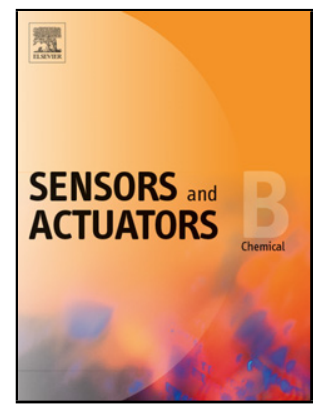

PII: S0925-4005(17)30591-9

DOI: http://dx.doi.org/doi:10.1016/j.snb.2017.03.164

Reference: SNB 22076

To appear in: Sensors and Actuators B

Received date: 27-9-2016

Revised date: 27-3-2017

Accepted date: 30-3-2017

Please cite this article as: $\{\mathrm{http}: / / \mathrm{dx}$. doi.org/

This is a PDF file of an unedited manuscript that has been accepted for publication. As a service to our customers we are providing this early version of the manuscript. The manuscript will undergo copyediting, typesetting, and review of the resulting proof before it is published in its final form. Please note that during the production process errors may be discovered which could affect the content, and all legal disclaimers that apply to the journal pertain. 


\section{WHEAT GLUTEN, A BIO-POLYMER TO MONITOR CARBON DIOXIDE IN FOOD PACKAGING: ELECTRIC AND DIELECTRIC CHARACTERIZATION}

Fabien Bibi ${ }^{\mathrm{a}}$, Carole Guillaume ${ }^{\mathrm{a}}$, Nathalie Gontard ${ }^{\mathrm{a}}$, Brice Sorli ${ }^{\mathrm{b} *}$

aJoint Research Unit Agropolymers Engineering and Emerging Technologies, UMR 1208 INRA/SupAgro/UMII/CIRAD, 2 Place Pierre Viala, 34060, Montpellier, France.

bInstitut d'Electronique et des Systèmes, Université Montpellier 2, 860 Rue Saint-Priest, 34090 Montpellier, France.

*Author to whom correspondence should be addressed: B. SORLI, Institut d'Electronique et des Systèmes, Université de Montpellier, 860 Rue Saint-Priest, 34090 Montpellier, France. Tel: +33 (0) 4671432 35. Email: brice.sorli@ ies.univ-montp2.fr

\section{Highlights}

- Novel study based on wheat gluten development for monitoring carbon dioxide in food packages.

- High coupling potential of wheat gluten with ultra-high frequency radio frequency identification systems.

- Retro-simulation for the determination of dielectric permittivity and loss.

- Linear increase in dielectric permittivity and dielectric loss in controlled carbon dioxide conditions.

- Interaction of carbon dioxide with wheat gluten network. 
- Determination of the sensitivity of wheat gluten as a function of carbon dioxide.

\begin{abstract}
The use of wheat gluten as sensing material to detect carbon dioxide is a promising approach. The dielectric properties of wheat gluten are modified in contact with carbon dioxide gas at high relative humidity $(90 \%)$ and at a temperature of $25^{\circ} \mathrm{C}$ due to a structural change in the sensing material, where amino groups act as receptors to carbon dioxide molecules. In the present study, the effects of carbon dioxide on the electrical and dielectric properties of wheat gluten at $20 \%$ and $90 \%$ of relative humidity (usually found in food packaging) are determined and discussed. At $90 \%$ of relative humidity, a linear increase of the dielectric permittivity and dielectric loss was observed with a significant hysteresis which increased with the number of carbon dioxide treatment cycles. One of the significant results is the increase in the dielectric permittivity from $7.01 \pm 0.07$ to $12.02 \pm 0.03$ with a sensitivity of $31.38 \pm 0.06 \mathrm{fF} / \% \mathrm{CO}_{2}$ measured at $868 \mathrm{MHz}$. The developed sensor is sought to be integrated in the design of UHF-RFID (ultrahigh frequency - radio frequency identification) systems working at $868 \mathrm{MHz}$.
\end{abstract}

\title{
1 Abbreviations
}

Fabien Bibi received a Master Degree in Sensors and Associated Systems from the University of Montpellier (France) in 2012 and received his PhD at "I'Institut National de la Recherche Agronomique" (INRA) SupAgro in Montpellier, France in 2015. His PhD was entitled: Study of dielectric properties of vegetal proteins at high frequency for the development of green RFID bio-sensors to be interfaced with passive UHF RFID systems. His main research interests are in the development of capacitive and resistive sensors, to be coupled to RFID tags for intelligent packaging and food chain monitoring. 
Keywords: Dielectric properties; wheat gluten; carbon dioxide sensor; interdigital capacitors; RFID.

\section{Introduction}

The control of carbon dioxide concentration in food packages is important and necessary for the extension of food shelf-life. Production of carbon dioxide in food packages is not only due to the development of micro-organisms, but also to respiring products such as fruits and vegetables $[1,2]$. In the goal of maintaining high quality food products, the partial or complete elimination of carbon dioxide is essential in modified atmosphere packaging (MAP) [3]. Fresh products such as strawberries, cherries, broccoli and mushrooms benefit from a high carbon dioxide concentration level up to $20 \%$, whereas other products for e.g. lettuce, tomatoes and pears suffer from carbon dioxide concentration of above 2\% [4]. Carbon dioxide is not only an active gas in MAP, but is also known to be a marker of food degradation [5] and an indicator of microorganism growth, responsible for food spoilage [6]. Monitoring carbon dioxide in food packages would thus give a better control on the evolution of food metabolism and meet the consumers' demand for high quality food products. To reach this objective, a natural polymer has been selected according to its physico-chemical properties, electric and dielectric properties and its close mimicking behavior of food products: wheat gluten.

Wheat gluten has been broadly studied for its gas properties [2] and increasingly investigated for its unique mass transfer properties [7-10]. The high permeability of wheat gluten to carbon dioxide and (to a lower extent) oxygen resulted in a high permselectivity (ratio of carbon dioxide permeability to oxygen permeability) of the material [2], making them interesting for food packaging applications, such as fresh fruit and vegetable packages [10,4,11]. 
In addition to these properties, wheat gluten contains different types of bonds such as electrostatic interactions and hydrogen bonds [12-15] which interact with the matrix. These bonds give rise to strong dipole-dipole interactions, sharing of electron pairs between atoms (stable electronic configuration) and electrical interaction of low intensity between atoms and molecules [16-19]. Wheat gluten is thus considered as a polarizable material, having dielectric properties (permittivity and dielectric loss). Most of the work carried on wheat gluten was performed on its gas transfer properties as aforementioned and on the electrical behavior of wheat gluten dough or powder at $200 \mathrm{MHz}, 915 \mathrm{MHz}, 2000 \mathrm{MHz}, 10000 \mathrm{MHz}, 16000 \mathrm{MHz}$ and at $20000 \mathrm{MHz}$ [12,20-22], but has never been studied as a potential film-based material for carbon dioxide monitoring, relying on its dielectric property variations at $868 \mathrm{MHz}$. The electric and dielectric properties of wheat gluten are also known to be sensitive to carbon dioxide [23] and could be used for monitoring packaging headspace in intelligent packaging systems.

Conforming to literature, the impact of carbon dioxide on polymers has been studied in several ways. FTIR spectroscopy has been performed on protein films exposed to high pressure carbon dioxide to evidence conformation changes in the films [24]. Under normal conditions, the permeability of carbon dioxide has been studied for modified atmosphere packaging applications $[1,25]$ and for determining the permselectivity which is the ratio of carbon dioxide and oxygen permeability $[1,2,26]$. The study of the influence of relative humidity on the sorption and permeability of carbon dioxide gas in wheat gluten proteins [2,27] has also been performed.

Principally based on the development of sensors, Stegmeier et al. [28] studied the interaction of carbon dioxide and humidity with amino group systems for the development of carbon dioxide sensors working at room humidity. Endres et al. [29] studied and developed a synthetic polymer capacitive sensor system which suppresses the relative humidity effects. However, the Actuators B Chemical, 250, 76-84. DOI : 10.1016/j.snb.2017.03.164 
dielectric properties of natural polymers as a function of carbon dioxide concentration at high relative humidity in the objective to be used as sensors have not been studied.

In the present work, the impact of carbon dioxide on the electrical and dielectric properties of wheat gluten protein, used as sensor, is determined at low and high relative humidity value ( $20 \%$ and $90 \%$ ), and at a constant temperature of $25^{\circ} \mathrm{C}$. Interdigital capacitors (IDCs) were manufactured to have a high surface/thickness ratio and high exposure to the surrounding atmosphere. The IDC was placed in a climatic chamber where relative humidity, temperature, $\mathrm{CO}_{2}$ gas flow and pressure were controlled. It was essential to control and maintain constant relative humidity and temperature due to the sensitivity of wheat gluten to these parameters. Electrical measurements performed with the IDC were used for identifying the dielectric permittivity and loss by retro-simulation of wheat gluten layer as a function of carbon dioxide concentration. The dielectric permittivity and loss obtained are further discussed in the objective of using wheat gluten for carbon dioxide monitoring coupled to UHF-RFID systems.

\section{Materials and methods}

\subsection{Interdigital capacitor (IDC) sample}

The design of the IDC system was performed using ANSOFT® software, which is a high performance electromagnetic simulation software. The IDC system design technique was already developed in a previous study [30]. In order to have an IDC system (figure 1 (a)) having the desired frequency range (up to $1000 \mathrm{MHz}$ ), the following geometrical dimensions were used: W2=0.4 mm, E2=0.4 mm, L2=10 mm, C2=2 mm, I2=1 mm, J2=7.4 mm, G2=12.4 mm, number of fingers $(\mathrm{N})=8$ and with a substrate (FR4) dielectric permittivity of 4.8 .

The designed IDC systems were manufactured by CIRLY, France (figure 1 (b)), in order to have homogeneity on all samples. The IDC system electrodes are made of copper metal deposited on a prefabricated circuit board made of a composite of glass fiber reinforced epoxy 
resin (thickness $1.6 \mathrm{~mm})$. The thickness of the electrode fingers $(17 \mu \mathrm{m})$ being fixed by the manufacturer, were also kept fixed in the design process.
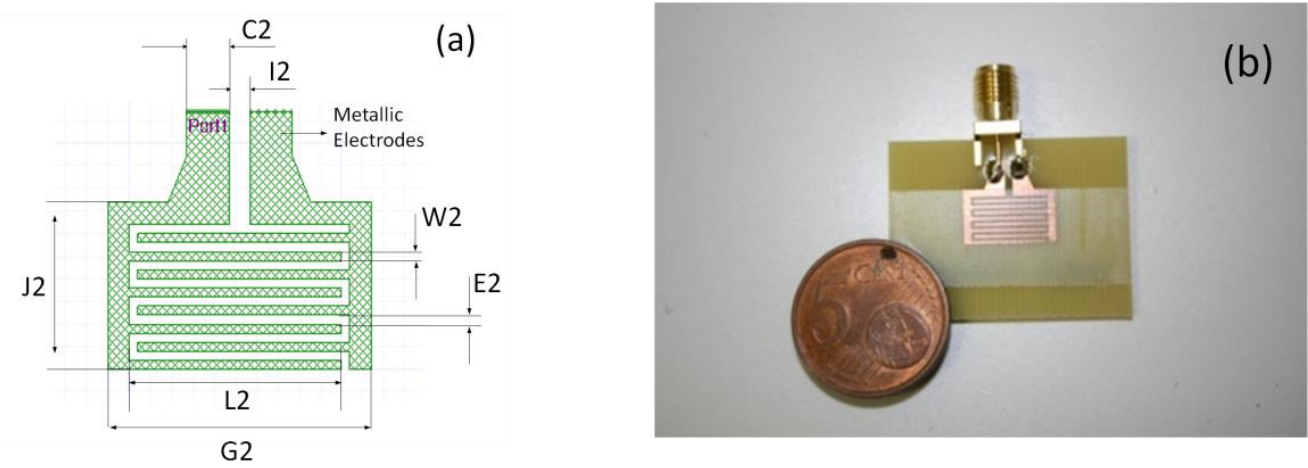

Figure 1: Designed interdigital capacitor (a), manufactured interdigital capacitor system casted with wheat gluten having a capacitive behavior up to $1000 \mathrm{MHz}(b)$.

\subsection{Wheat gluten sample}

\subsubsection{Solution preparation}

Wheat gluten (amygluten 110) powder (7.2 wt \% of moisture and $76.5 \mathrm{wt} \%$ of protein, $14.2 \%$, $8.1 \%$ and $1.2 \%$ dry weight of carbohydrates, lipids and ashes respectively) was provided by Amylum (Mesnil St Nicaise, France). Sodium sulfite and acetic acid were obtained from SigmaAldrich (St Quentin, France). The wheat gluten solution was prepared at room temperature $\left(25^{\circ} \mathrm{C}\right)$ and humidity $(50 \% \mathrm{RH}) .30 \mathrm{~g}$ of wheat gluten powder was dispersed under shaking in $50 \mathrm{~mL}$ of a sodium sulphite solution $(0.06 \mathrm{~g}$ sodium sulphite for $50 \mathrm{~mL}$ of distilled water) to reduce disulfide bonds in the wheat gluten protein. The mixture was left to settle for 30 minutes. The $\mathrm{pH}$ of the solution was adjusted to 4 by adding $3.4 \mathrm{~mL}$ of $50 / 50 \mathrm{v} / \mathrm{v}$ solution of acetic acid. The mixture was stirred. The solution was finally adjusted to $130 \mathrm{~mL}$ by adding deionized water and mixed. The prepared wheat gluten solution was left degassing under vacuum for one night [31,32] and used within one week.

\subsubsection{Sample preparation - Solvent Casting method}

$1 \mathrm{~mL}$ of wheat gluten solution was cast onto IDC systems using an E409 blade coater from Erichsen (France), to cover the whole comb-like structure. The coater was equipped with the 
number 4 blade having spires of $0.51 \mathrm{~mm}$, to create a humid film deposit having a thickness of $40 \mu \mathrm{m}$. The speed was set to $1 \mathrm{~mm} / \mathrm{s}$. The sample was left to dry for $24 \mathrm{~h}$ at room temperature and at $50 \%$ of relative humidity.

\subsection{Electrical characterization - Measurement of wheat gluten under dynamic} flow of wet carbon dioxide via interdigital capacitor systems (IDC systems)

Wheat gluten coated IDC system was subjected to carbon dioxide treatment. The apparatus used is a climate control system provided by Hiden Isochema from England. The climate control system provides unique controlled climate, allowing command of atmospheric composition in terms of gases such as nitrogen, carbon dioxide and oxygen, controlling temperature, pressure, as well as relative humidity. The total control of the climate is possible due to sensors connected to the chamber: temperature sensor $\left( \pm 0.1^{\circ} \mathrm{C}\right)$, relative humidity sensor $( \pm 0.1 \%)$, gas flow rate sensor $( \pm 1 \%)$ and pressure sensor $( \pm 0.05 \%)$ were provided.

The apparatus is made up of two water baths, one equipped with a vapor generator, a chamber in which the atmosphere is controlled, an outer cylinder jacket, glove cuff, a heated power supply and a process control interface. The system is represented in figure 2. 


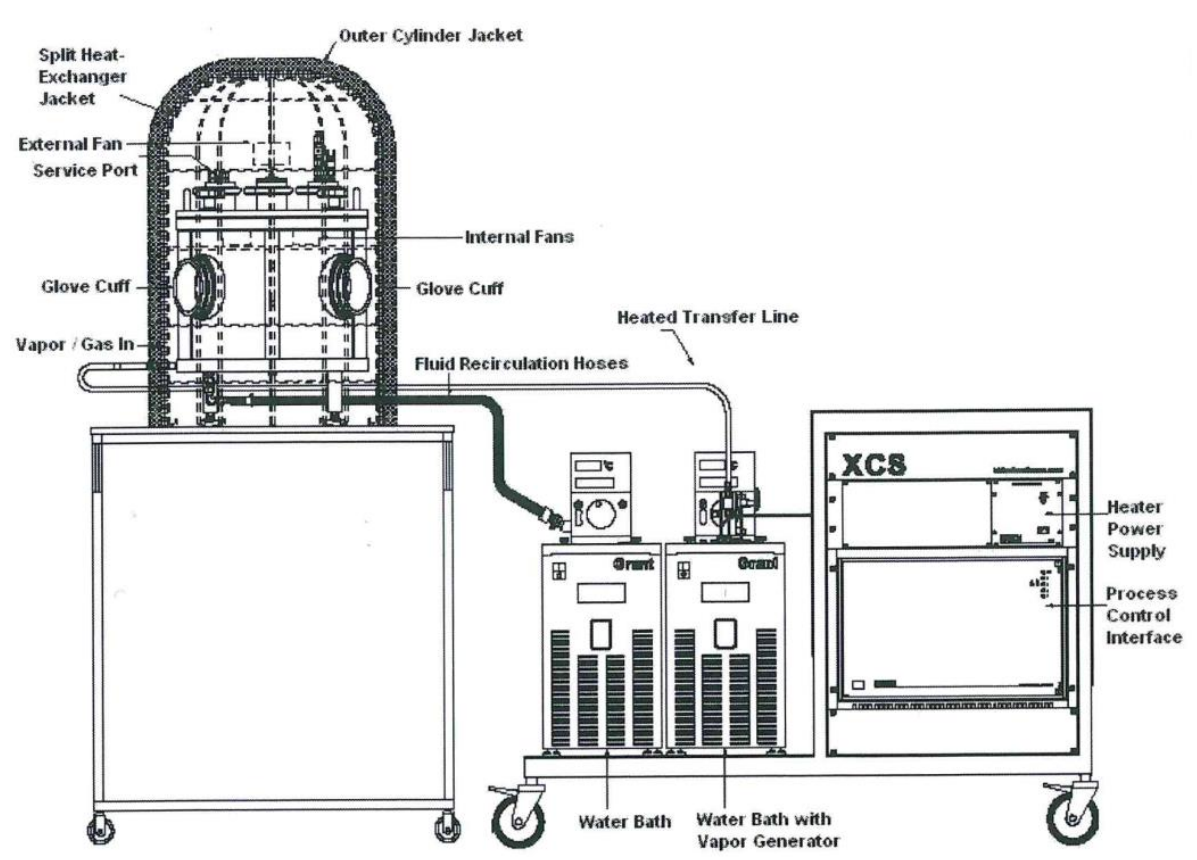

Figure 2: Climate control system. From Hiden Isochema, England.

The carbon dioxide concentration was varied from $0 \%$ to $40 \%$. Relative humidity was fixed in the chamber, first at $20 \%$ and then at $90 \%$, and temperature was fixed at $25^{\circ} \mathrm{C}$. The flow of gas (nitrogen and carbon dioxide) was fixed to $600 \mathrm{~mL} / \mathrm{min}$ for 1 hour at each carbon dioxide concentration to fill rapidly the chamber, and then fixed to $200 \mathrm{~mL} / \mathrm{min}$ for further processing of the experiment. To ensure complete equilibrium of wheat gluten coated IDC system to the surrounding atmosphere, the experiment was carried out on 3 days for each carbon dioxide concentration level. At the end of the allocated time, the automatic control of the system shifts to the next carbon dioxide concentration. Three increasing and decreasing carbon dioxide cycles were performed.

For electrical measurements, a coaxial cable, a Vector Network Analyzer (VNA), a hygrometer (Rotronic Hygromer) and a host computer were necessary.

Impedance measurements were performed using a VNA (Hewlett-Packard 8753D) with an open-ended coaxial cable, connected to the IDC system through a coaxial connector (SMA connector). The whole system composed of: the VNA, the coaxial cable and SMA connectors 
(SubMiniature version A) was calibrated using three different types of loads: open circuit, short circuit and a $50 \Omega$ load to rigorously characterize the electrical properties of the IDC system. The calibration was performed over a frequency range of $30 \mathrm{MHz}$ to $3000 \mathrm{MHz}$. It should be specified that the results presented in the scope of this work are at $868 \mathrm{MHz}$, being the working frequency of UHF passive RFID systems, with which wheat gluten is sought to be interfaced.

The coaxial cable was fixed to the extent possible to avoid stray capacitors due to cable movements after calibration, before connecting the IDC system. The latter was inserted into the climate control system where carbon dioxide gas concentration, relative humidity and temperature are controlled. A hygrometer was used to verify the relative humidity value. The temperature was fixed at $25^{\circ} \mathrm{C}$ during the whole experiment. In all cases, the IDC systems were positioned in the middle of the chamber to provide equal atmosphere interaction on the whole surface area of the sensor.

A host computer was connected to the VNA for data acquisition. The impedance real and imaginary components, as well as frequency were acquired at fixed time intervals (30 minutes for each measurement). These electrical properties were recorded (as triplicates) by a program developed on Labview software and data was saved in text files. The experimental set-up for electrical property measurements is given in figure 3 (a).

The IDC system is represented by the equivalent resistance capacitance (RC) circuit in figure 3 (b). The associated real and imaginary parts are represented by equation 1 and equation 2 respectively, where both are frequency dependent [33,34]. 

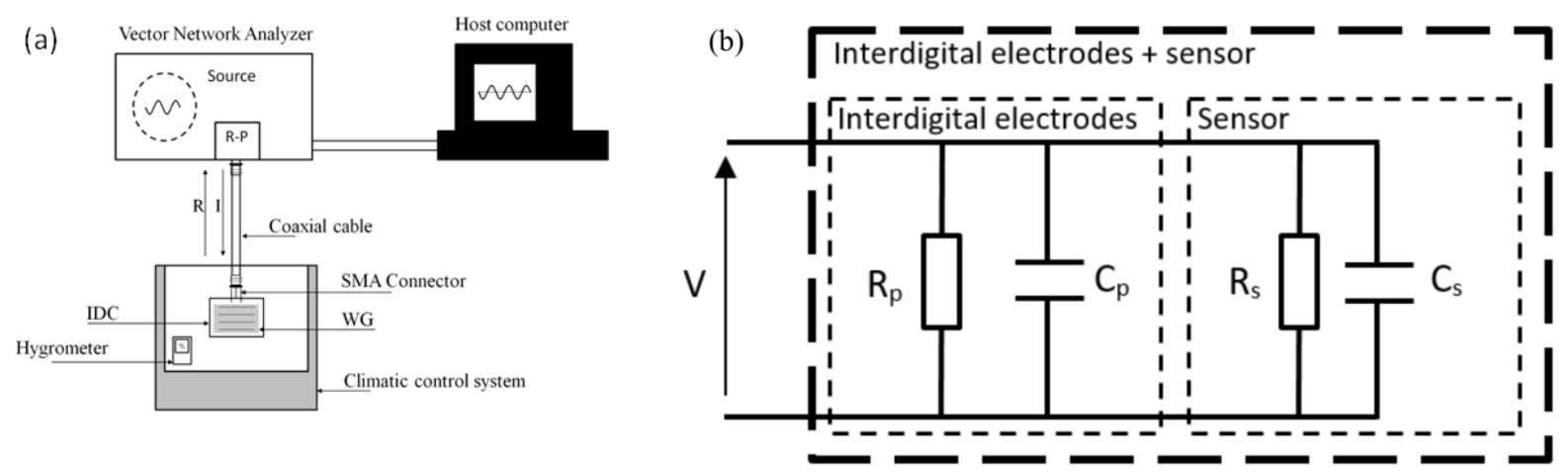

Figure 3: Experimental setup for electrical property measurements in controlled conditions of humidity, carbon dioxide and temperature (a), and resistance capacitance parallel circuit Equivalent model for IDC system (b).

Where R-P represents the reflection port, I the incident signal, $\mathrm{R}$ the reflected signal, $R_{p} \& C_{p}$ the resistance and the capacitance of the interdigital circuit, $R_{S} \& C_{S}$ the resistance and capacitance of the sensor, $\omega$ the angular frequency and $\mathrm{V}$ the voltage applied to the circuit.

$$
\begin{aligned}
& Z_{r}=\frac{R_{T}}{1+\left(R_{T} C_{T} \omega\right)^{2}} \\
& Z_{\text {img }}=-\frac{R_{T}^{2} C_{T} \omega}{1+\left(R_{T} C_{T} \omega\right)^{2}}
\end{aligned}
$$

Where $R_{T}$ is $R_{p}$ and $R_{S}$ in parallel, and where $C_{T}$ is $C_{P}$ and $C_{S}$ in parallel.

\subsection{Identification of dielectric properties of materials by retro-simulation of IDC systems}

The identification of the dielectric properties of wheat gluten was performed by simulation with ANSOFT® software using geometrical and substrate (FR4) parameters of the designed IDC system. The identification procedure was developed in a previous study [30] where the permittivity and dielectric loss were obtained by comparing the simulated impedance values to the measured values at the specified frequency. The only modification performed to the IDC system was the addition of the wheat gluten layer on top. This layer represented the dielectric whose permittivity and loss were varied and re-injected in the simulation procedure. By 
comparing the simulated impedance values to the measured ones at the specified frequency and upon matching, the dielectric permittivity and loss of the wheat gluten layer were obtained.

\section{Results and discussion}

\subsection{Effects of carbon dioxide on electrical properties of wheat gluten at low relative humidity value}

The impact of carbon dioxide was determined at low relative humidity (20\%) on the wheat gluten network. The capacitance was calculated using the resistance capacitance model represented in figure 3 (b). As illustrated in figure 4, the capacitance value given by the VNA is stable for the increasing and decreasing carbon dioxide concentrations at $20 \%$ of relative humidity and at $25^{\circ} \mathrm{C}$, and to a further extent, indicates that the dielectric properties (not determined in the present case) of wheat gluten are not influenced by carbon dioxide at low relative humidity. In its dry state, wheat gluten presents strong protein-protein interactions, instead of protein-water interactions, forming a dense network [35], probably due to high glutamine content (45\%) linked together by hydrogen bonds (cross-linked glutamine). The $20 \%$ relative humidity results only in bound water content (3.6\% dry basis) with the wheat gluten network. According to studies performed by Gontard et al. $[4,36]$, at this water content, wheat gluten presents extremely low permeability to gases such as carbon dioxide and oxygen. The transport of carbon dioxide in the wheat gluten network is limited and the gas is consequently not able to bind with high energy sorption sites which are not accessible. Therefore, it can be assumed that wheat gluten does not show its most interesting dielectric properties at low relative humidity, having a gas barrier behavior. 


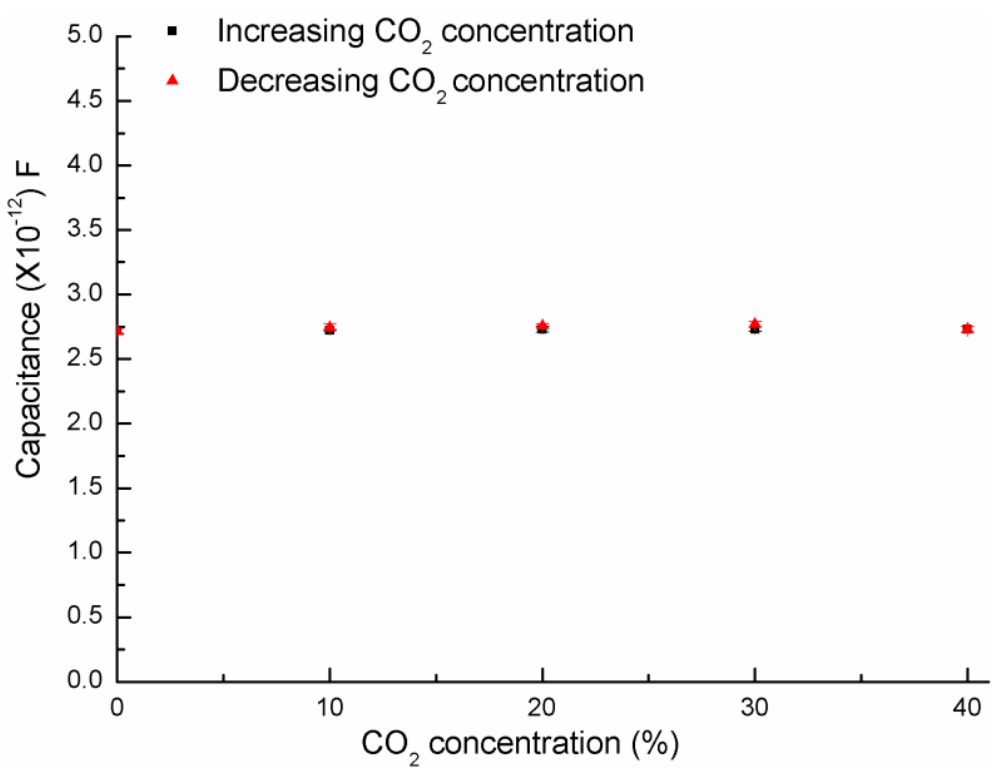

Figure 4: Capacitance as a function of carbon dioxide concentration at $20 \%$ of relative humidity and $25^{\circ} \mathrm{C}$.

\subsection{Effects of carbon dioxide at high relative humidity}

\subsubsection{Impact of carbon dioxide on electrical properties}

According to Gontard et al. and Mujica-Paz and Gontard [4,26,36], wheat gluten exhibits its most interesting properties at high relative humidity (90\%). This aspect was also observed for dielectric properties of wheat gluten at $90 \%$ of relative humidity. Figure 5 illustrates the capacitance of the wheat gluten coated IDC system as a function of time from $0 \%$ to $40 \%$ of carbon dioxide at $90 \%$ of relative humidity and at $25^{\circ} \mathrm{C}$. As it can be observed, the capacitance increases with carbon dioxide concentration, in a stepwise manner from $7.32 \pm 0.01 \mathrm{pF}$ to $8.19 \pm 0.02 \mathrm{pF}$. The capacitance mimics perfectly the change in carbon dioxide concentration. The standard deviation on the capacitance is low indicating that the measurements are repeatable. It was essential to keep relative humidity constant at $90 \%$, as fluctuations in its value would obscure the effects of carbon dioxide on the electrical properties of wheat gluten. It is also noticeable on figure 5, that even after flushing with nitrogen gas at the end of the cycle, the process is not reversible in experimental conditions as the capacitance is higher compared to the beginning, indicating a non-reversible change in the structure of wheat gluten. 


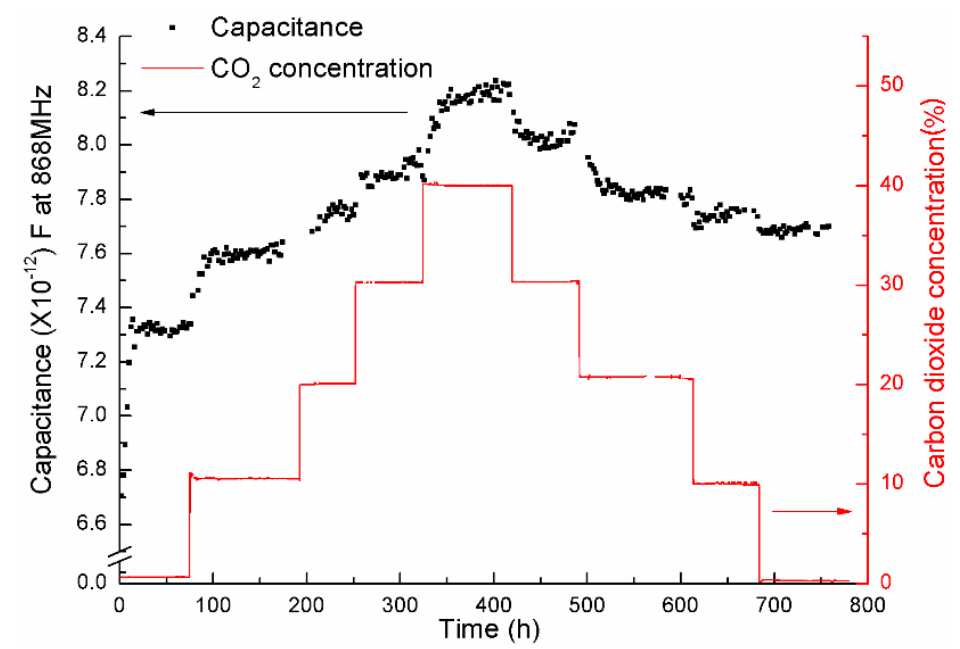

Figure 5: Capacitance measurements as a function of time, for an increasing-decreasing cycle, at $90 \%$ of relative humidity and $25^{\circ} \mathrm{C}$.

3.2.2 Impact of carbon dioxide on dielectric properties of wheat gluten at $90 \%$ of relative humidity

Figure 6 and figure 7 show the dielectric loss and the dielectric permittivity of wheat gluten respectively. A linear increase is recorded for both dielectric properties with carbon dioxide concentration. The dielectric loss increases from $0.51 \pm 0.01$ to $1.09 \pm 0.02$ and the dielectric permittivity increases from $7.81 \pm 0.07$ to $12.02 \pm 0.03$. With decrease in carbon dioxide concentration, the dielectric loss shifts back to $0.68 \pm 0.01$ and the dielectric permittivity to $9.42 \pm 0.03$. This indicates that the sensor is not completely reversible as observed for capacitance measurements. 


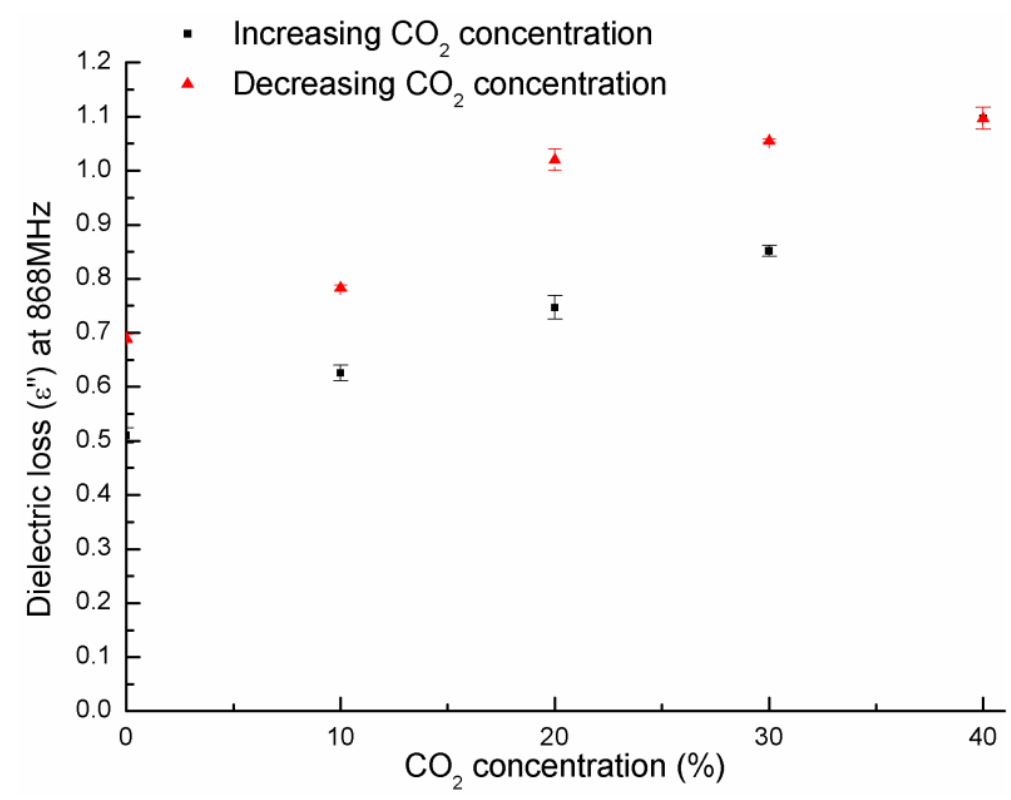

Figure 6: Dielectric loss value as a function of carbon dioxide concentration, for an increasingdecreasing cycle, at $90 \%$ of relative humidity and $25^{\circ} \mathrm{C}$.

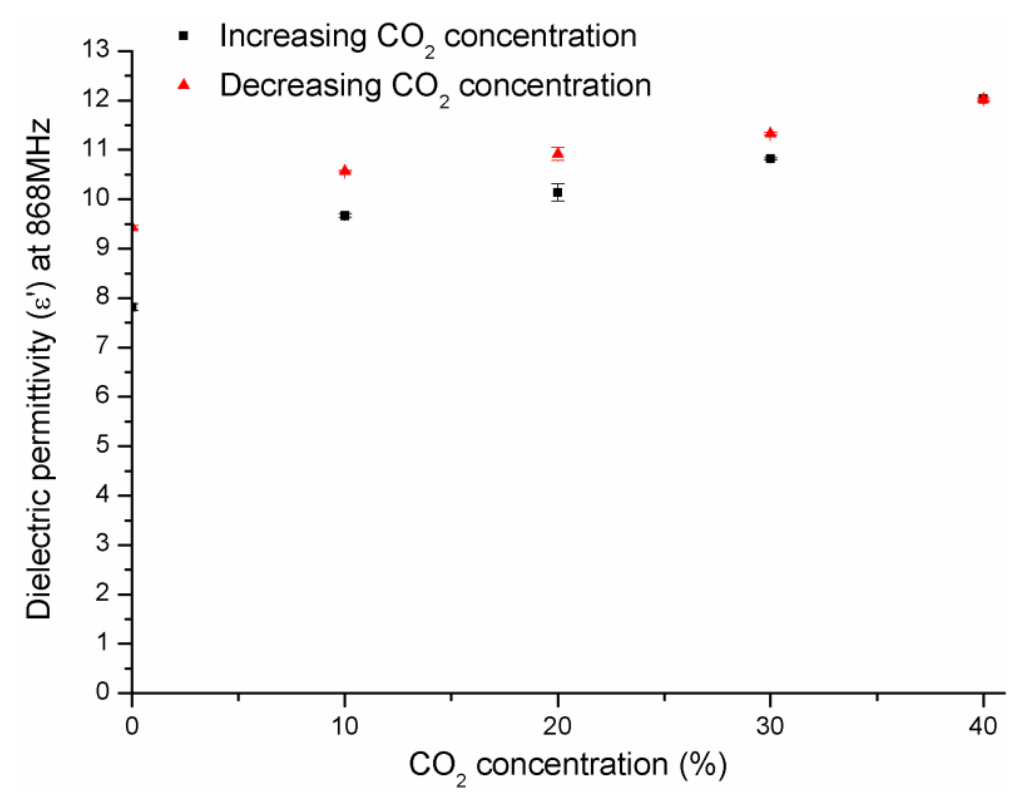

Figure 7: Dielectric permittivity value as a function of carbon dioxide concentration, for an increasing-decreasing cycle, at $90 \%$ of relative humidity and $25^{\circ} \mathrm{C}$.

Regarding figure 8 , it is also shown that the irreversibility kept increasing while performing 3 increasing and decreasing carbon dioxide cycles. This is due to the rate of change of the dielectric property values until irreversibility. The higher the concentration of $\mathrm{CO}_{2}$ imposed, the less the number of cycles required to reach irreversibility. As it can be observed in figure 8 , at $0 \%$ of carbon dioxide, the gap between the cycles keeps increasing, up to a maximum change of $3.24 \pm 0.08$ (at $0 \%$ of carbon dioxide) of the permittivity. Consequently, the permittivity 
values reached at $0 \%$ of carbon dioxide at the end of the $3^{\text {rd }}$ cycle is $11.05 \pm 0.01$, which is close to the permittivity value $(11.97 \pm 0.13)$ at $40 \%$ of carbon dioxide. This drift indicates that carbon dioxide intake by wheat gluten at each cycle, associated with relative humidity causes further change in the protein layer. No gaps are detected at $40 \%$ of carbon dioxide for the 3 cycles, where the permittivity value reached remains around $11.97 \pm 0.13$.

On an applicative point of view, the reversibility is not a crucial factor, to the extent that, with food fermentation, carbon dioxide content in packaging increases, followed by the disposal of the product. The sensor would therefore give information about the highest level of carbon dioxide reached.

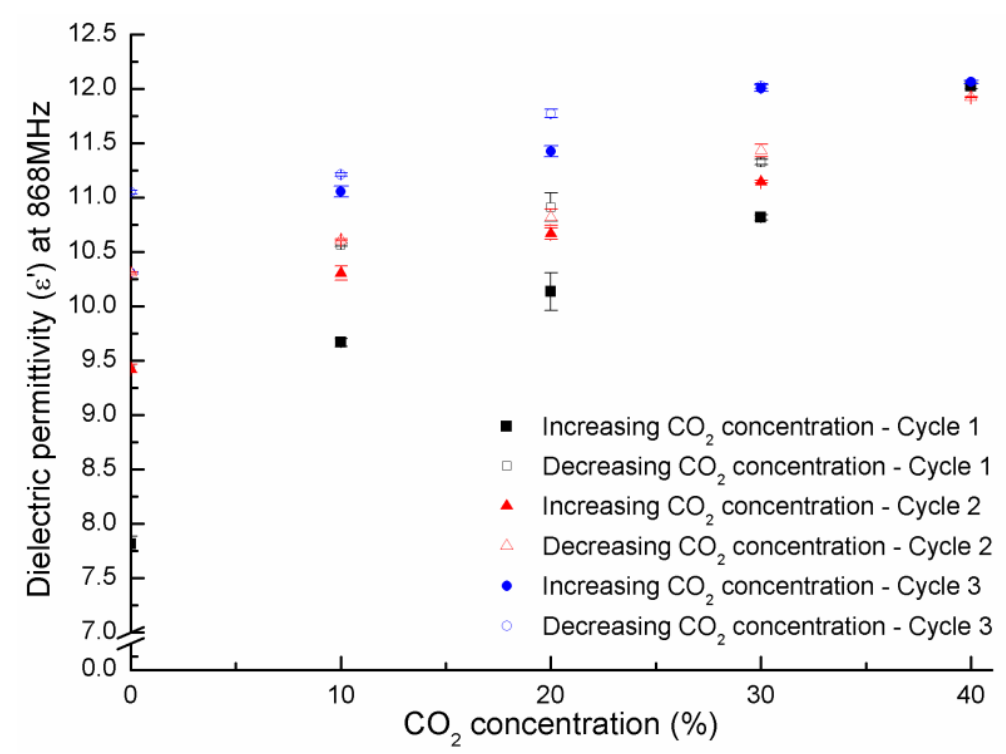

Figure 8: Dielectric permittivity value as a function of carbon dioxide concentration, for 3 increasing-decreasing cycles, at $90 \%$ of relative humidity and $25^{\circ} \mathrm{C}$.

Understanding effects of carbon dioxide: At $90 \%$ of relative humidity, free water accumulates in clusters within the wheat gluten network (water content: $7.4 \times 10^{-1} \mathrm{gg}^{-1}(23.5 \%)$ dry basis), enhancing carbon dioxide transport, due to its high solubility in water. Indeed, it was proved by several studies $[36,37]$ that a high water content in the film would decrease the glass transition temperature $\left(110^{\circ} \mathrm{C}\right.$ for dry wheat gluten $)$. The penetration of water within the macromolecular chains inhibits protein-protein interactions, favoring protein-water 
interactions. In addition, with increase in relative humidity, giving a water content of $2.2 \times 10^{-1} \mathrm{gg}^{-1}$ dry basis, the $\mathrm{T}_{\mathrm{g}}$ of wheat gluten decreases to $25^{\circ} \mathrm{C}$, which is the temperature at which the present experiments were carried out. In addition, the calculated water content in the present situation is $7.4 \times 10^{-1} \mathrm{gg}^{-1}$ dry basis, indicating that wheat gluten was in a rubbery state, outlined by an increasing disorder, free volume and mobility of macromolecular chains, with a decrease in density of the network and reducing the intensity of physical junctions namely hydrogen bonds and hydrophobic interactions. Besides network plasticization, the complexity of wheat gluten might explain the diversity of potential interactions of carbon dioxide with the protein network, on a combined or dissolved form. As such, carbon dioxide might react or bound with chemical groups within the wheat gluten network resulting in the formation of several bonds. They can be: covalent binding through carbamination with lysine, electrostatic bindings with ionized lateral groups, hydrogen binding with glutamine residue, hydrophobic lateral groups or peptidic chain [27]. The formation of these bonds with the amide groups will modify the secondary structure of the protein [38].

As said previously, wheat gluten has a hydrophilic character and a high affinity to water molecules, at high relative humidity. It uptakes water considerably and the polymer matrix undergoes a significant swelling, which leads to a remarkable increase in the gas sorption values ( $189 \times 10^{-4} \mathrm{~mol} / \mathrm{Pa} \cdot \mathrm{m}^{3}$ at $96 \% \mathrm{RH}$ compared to $2.8 \times 10^{-4} \mathrm{~mol} / \mathrm{Pa}^{3} \mathrm{~m}^{3}$ at $0 \% \mathrm{RH}$ ). In the dissolved form, one can suppose carbon dioxide to be in its ionic forms (for example $\mathrm{HCO}_{3}^{-}$) due to the catalyzed formation of bicarbonate species on the sorbent surface (wheat gluten surface) by the adjacent water molecules, together with the injection of protons $\left(H^{+}\right)[39]$, according to the dissociation equation of carbon dioxide (equation 3), and to the fraction of dissolved carbon as function of $\mathrm{pH}$ (figure 9). Indeed, acidification of wheat gluten may take place reducing the $\mathrm{pH}$ of the plasticized medium [40]. The injection of these new charges, Actuators B Chemical, 250, 76-84. DOI : 10.1016/j.snb.2017.03.164 
together with their bonding with the polymeric chains, through hydrogen bindings, electrostatic bindings, covalent bindings and even hydrophobic bindings with chemical groups of aminoacid, will contribute in increasing the number of dipole-dipole interactions, as well as electrical conduction (for residual free charges) within the network.

High relative humidity is thus essential, to promote carbon dioxide solubility within the wheat gluten network, impacting the structure and consequently the dielectric permittivity and loss, both subjected to a linear increase.

$$
\mathrm{CO}_{2}+\mathrm{H}_{2} \mathrm{O} \leftrightarrow \mathrm{H}_{2} \mathrm{CO}_{3} \leftrightarrow \mathrm{H}^{+}+\mathrm{HCO}_{3}^{-} \leftrightarrow 2 \mathrm{H}^{+}+\mathrm{CO}_{3}^{2-}
$$

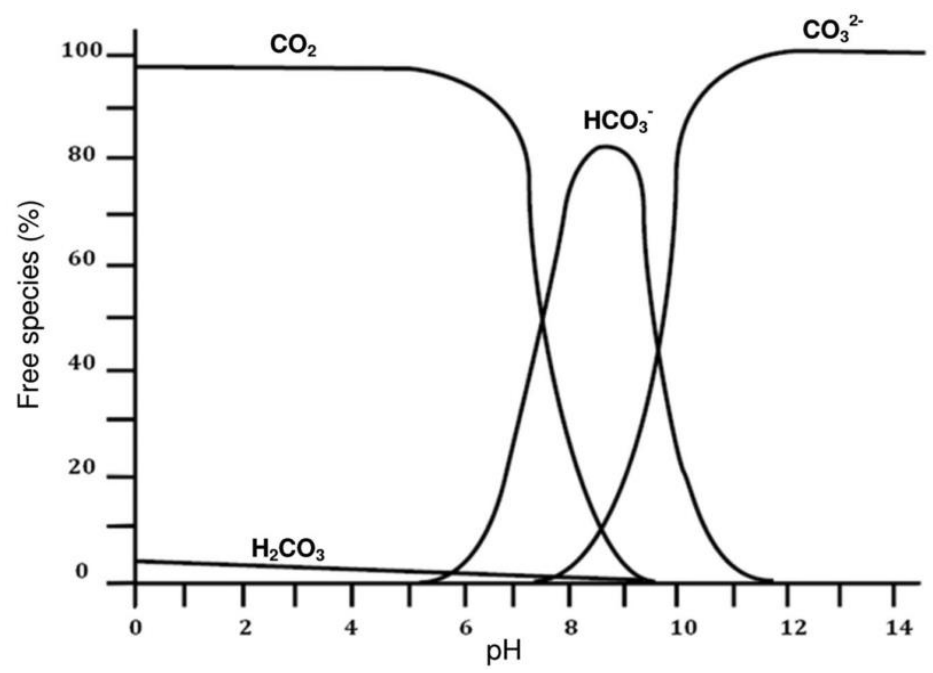

Figure 9: Fraction of dissolved carbon dioxide as a function of $\mathrm{pH}$. Adapted from Chaix et al. and Hofland et al. [39,41] and Daniels et al. [40].

Comparing the physico-chemical properties of synthetic films such as polyimides, it was proved that their carbon dioxide permeability at the dry state (and at $25^{\circ} \mathrm{C}$ ) had a higher value $(2825$ amol. $\left.s^{-1} \cdot m^{-1} \cdot P a^{-1}\right)$ than wheat gluten $\left(88\right.$ amol $\left.\cdot s^{-1} \cdot m^{-1} \cdot P a^{-1}\right)$. However, in the hydrated state, the permeability of carbon dioxide gas tends to decrease for the synthetic film (1379 amol.s $\left.s^{-1} \cdot m^{-1} \cdot \mathrm{Pa}^{-1}\right)$ and increase for wheat gluten $\left(536\right.$ amol.s $\mathrm{s}^{-1} \cdot \mathrm{m}^{-1} \cdot \mathrm{Pa}^{-1}$ at $50 \% \mathrm{RH}$ and $22353 \mathrm{amol} \cdot \mathrm{s}^{-1} \cdot \mathrm{m}^{-1} \cdot \mathrm{Pa}^{-1}$ at $\left.85 \% \mathrm{RH}\right)[26,42]$. The same observations can be made for the carbon dioxide sorption values, where $35 \times 10^{-4} \mathrm{~mol} / \mathrm{Pa} . \mathrm{m}^{3}$ was obtained for polyimide-silica 
composites [43] compared to $2.8 \times 10^{-4} \mathrm{~mol} / \mathrm{Pa} . \mathrm{m}^{3}$ for wheat gluten [27], both in a dry state; and an increase to $189 \times 10^{-4} \mathrm{~mol} / \mathrm{Pa} . \mathrm{m}^{3}$ for wheat gluten [27] was noted, but not specified for polyimides. In agreement with permeability values, the same assumptions can be made. Polyimides are rather hydrophobic with molecular chain groups showing very low affinity to polar compounds. The solubility of water is lower than a few percents (mass basis). Consequently, the polymer swelling is not significant and negligible in the presence of water, explaining the decrease in the permeability and sorption of carbon dioxide, as relative humidity increases.

Table 1 summarizes different materials used as sensing element for the detection of carbon dioxide, as well as their detection principle. At a first glance, it can be observed that most of the materials found in literature, being polymers or metals, are based on a color change as detection principle. None of them are based on the dielectric phenomena that may eventually be altered in contact with the different forms of carbon dioxide. Several studies are focused on the potentiometric detection type and conductivity. They depend on the change in the concentration of ions, due to a change in $\mathrm{pH}$ [44], modifying the measured potential [44,45] or conductivity [46-48]. On the other hand, as specified by Neethirajan et al. [49], some potentiometric sensors display poor repeatability and reproducibility of potentiometric responses. Depending on the material used by the authors, some of them require extreme conditions for the correct operation of the sensor. For instance, $400^{\circ} \mathrm{C}$ is required as stated by Hong et al. [45]. This is not applicable in the agrifood sector where fresh produce are often stored at much lower temperatures. These sensors thus present some drawbacks. According to the studies, they are often bulky, have a complex detection system (Severinghaus concept) and need several elements for realizing a proper measurement. As such, the sensor developed by Varlan and Sansen [46], requires a reaction between carbon dioxide and bicarbonate solution, in a cavity covered with a gas permeable membrane. Admittedly, this system is very interesting 
as it allows performing carbon dioxide measurements, without having relative humidity interferences. In agrifood applications, this concept could be of main interest, as they target fresh produce containing high relative humidity within the packaging. This would thus give a measure of only carbon dioxide concentration. However, the system that needs to be set up in the packaging would alter its integrity due to potential cables needed for performing measurements. The use of a wireless detection system would be the ideal system to be established.

\subsection{Sensitivity and selectivity}

Sensitivity: A better insight of the sensor's response can be obtained using the sensitivity. The behavior of the capacitance as a function of carbon dioxide being a linear increase, the sensitivity was simply calculated using equation 4 , and is the derivative of the capacitancecarbon dioxide concentration curve (figure 10).

$$
S=\left(\frac{C_{C O_{2 f}}-C_{C O_{2 i}}}{\% C O_{2 f}-\% C O_{2 i}}\right)
$$

Where $C_{\mathrm{CO}_{2 f}}$ and $C_{\mathrm{CO}_{2 i}}$ represent the capacitance values of the final and initial carbon dioxide concentration respectively, and $\% \mathrm{CO}_{2 f}$ and $\% \mathrm{CO}_{2 i}$ represent the final and initial carbon dioxide concentration respectively (in the present case $40 \%$ and $0 \%$ ).

The change in the capacitance value (figure 10) occurring between $0 \%$ and $40 \%$ of carbon dioxide results in a sensitivity of $31.38 \pm 0.06 \mathrm{fF} / \% \mathrm{CO}_{2}$. This value is higher than other sensitivity values obtained by other authors for humidity $(21 \mathrm{fF} / \% \mathrm{RH}$ obtained by Oprea et al. [50]), meaning that the wheat gluten has a good sensitivity to carbon dioxide gas. However, the response time of the sensor towards carbon dioxide is longer than the response time towards relative humidity, which is quite limiting so far. In spite of this, concerning packed food having a shelf life of 7 days, the response time should not be a bottleneck. The sensitivity of other 
materials to carbon dioxide is also represented in table 1, giving an idea on how well-positioned is the wheat gluten sensor.

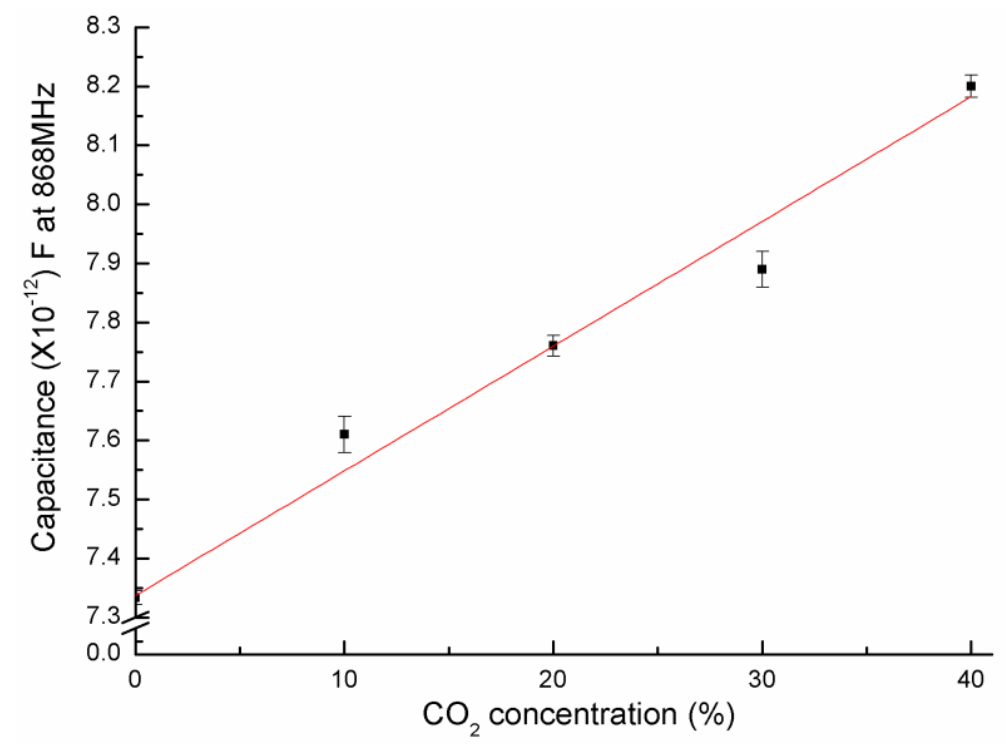

Figure 10: Capacitance sensitivity of wheat gluten coated IDC system as a function of carbon dioxide concentration.

Selectivity: As illustrated by the results in the present work, the biosensor is not selective and is dependent of relative humidity for the detection of carbon dioxide gas. This aspect is a bottleneck in most sensing devices as affirmed by Potyrailo et al. [51]. The authors state that water vapor is the most abundant and is a high concentrated interferent in ambient air, and that the sensitivity of almost all sensors to water vapor represents the largest challenge for their practical applications, resulting in a non-satisfactory gas-selectivity performance. One of the attractive solutions is to use a sensor exhibiting different response mechanisms to species of interest, in the present case, relative humidity and carbon dioxide, coupled to a transducer having multivariable signal transduction capability to detect these independent changes. The authors propose two solutions: the first approach consisted in the coupling of the sensor to a RFID antenna, altering its impedance response, and the second consisted in using a complementary sensor attached to the antenna and the chip that also altered the sensor's impedance response. The sensors were then calibrated according to the concentration of the analyte of interest. 
In the present study and for an application in real conditions, the selectivity should be taken with care, as the loss or gain in water and carbon dioxide production are two competing phenomena, rarely taking place simultaneously (relative humidity and temperature are imposed for storage in modified atmosphere packages) $[10,11]$. Consequently, the relative humidity in the packaging headspace remains constant while carbon dioxide concentration varies for one food product, and the sensitivity of the biosensor to the carbon dioxide gas should not be altered. However, for other applications of carbon dioxide monitoring, where variations of relative humidity are noted, this aspect could be inadequate, for example in cases where water mass transfer occurs from the product to the atmosphere within the packaging [27]. As observed in table 1, the sensor's performance is highly dependent on factors like relative humidity, temperature or solvent concentration. Focusing on relative humidity, in cases where relative humidity is low, the sensitivity of the sensor is also low. These observations bring to the conclusion that relative humidity is essential for gas detection in particular cases. 
Table 1: Materials used as carbon dioxide sensor and presentation of their detection principle and performance for application in food packaging 2 and agrifood sector.

\begin{tabular}{|c|c|c|c|c|c|c|}
\hline Material & Type & $\begin{array}{l}\text { Detection } \\
\text { principle }\end{array}$ & Sensitivity & Selectivity & $\begin{array}{l}\text { Limit } \\
\text { of } \\
\text { detectio } \\
n\end{array}$ & $\begin{array}{l}\text { Reference } \\
\mathrm{s}\end{array}$ \\
\hline $\begin{array}{l}\text { Wheat } \\
\text { gluten } \\
\text { (film) }\end{array}$ & $\begin{array}{l}\text { Natural } \\
\text { polymer }\end{array}$ & $\begin{array}{l}\text { Dielectric } \\
\text { detection }\end{array}$ & $\begin{array}{l}31.38 \pm 0.06 \\
\mathrm{fF} / \% \mathrm{CO}_{2}\end{array}$ & $\begin{array}{l}\text { Relative } \\
\text { humidity } \\
\text { dependent }\end{array}$ & $\begin{array}{l}40 \% \\
\mathrm{CO}_{2}\end{array}$ & $\begin{array}{l}\text { Present } \\
\text { Study }\end{array}$ \\
\hline $\begin{array}{l}\text { Photonic } \\
\text { opal film }\end{array}$ & $\begin{array}{l}\text { Crystals- } \\
\text { plastic } \\
\text { spheres }\end{array}$ & Color change & - & $\begin{array}{l}\text { No } \\
\text { dependency } \\
\text { specified }\end{array}$ & - & {$[48]$} \\
\hline $\begin{array}{l}\text { Polymer } \\
\text { hydrogel } \\
\text { based }\end{array}$ & Polymer & Color change & - & $\begin{array}{l}\text { Influx of } \\
\text { water used }\end{array}$ & - & {$[52]$} \\
\hline $\begin{array}{l}\text { Permeable } \\
\text { membrane }\end{array}$ & $\mathrm{pH}$-based & Color change & $\begin{array}{l}\text { Linked to the } \\
\text { equilibrium } \\
\text { constant } \\
\left(\mathrm{pK}_{\mathrm{A}}\right) \text { of } \mathrm{pH} \\
\text { indicator }\end{array}$ & $\begin{array}{l}\text { High } \\
\text { relative } \\
\text { humidity } \\
\text { and } \\
\text { temperature } \\
\text { dependent }\end{array}$ & $\begin{array}{l}25 \% \\
\mathrm{CO}_{2}\end{array}$ & [48] \\
\hline$\beta$-Alumina & $\begin{array}{l}\text { Solid } \\
\text { Electroly } \\
\text { tes }\end{array}$ & $\begin{array}{l}\text { Electrochemical } \\
\text { potentiometric - } \\
\text { need high } \\
\text { operating }\end{array}$ & $\begin{array}{l}-74.9 \\
\mathrm{mV} / \mathrm{ppm} \\
\text { and }-74 \mathrm{mV} / \\
\text { dec }\end{array}$ & $\begin{array}{l}\text { Temperatur } \\
\text { e dependent }\end{array}$ & $\begin{array}{l}10000 \\
\text { ppm }\end{array}$ & {$[45]$} \\
\hline
\end{tabular}




\begin{tabular}{|c|c|c|c|c|c|c|}
\hline & & $\begin{array}{l}\text { temperature } \\
\left(400^{\circ} \mathrm{C}\right)\end{array}$ & & & & \\
\hline $\begin{array}{l}\text { Polymer } \\
\text { membrane } \\
\text { (polysilox } \\
\text { ane) }\end{array}$ & Polymer & $\begin{array}{l}\text { Conductivity - } \\
\text { reaction of } \\
\text { carbon dioxide } \\
\text { and bicarbonate } \\
\text { solution in a } \\
\text { cavity covered } \\
\text { with a gas } \\
\text { permeable } \\
\text { membrane. } \\
\text { (Severinghaus } \\
\text { concept) }\end{array}$ & $\begin{array}{l}1.43 \mu \mathrm{Scm}^{-} \\
{ }^{1} /(\mathrm{mmHg})^{1 / 2}\end{array}$ & $\begin{array}{l}\text { Bicarbonate } \\
\text { solution } \\
\text { concentrati } \\
\text { on } \\
\text { dependent }\end{array}$ & $\begin{array}{l}80 \\
\mathrm{mmHg}\end{array}$ & [46] \\
\hline $\begin{array}{l}\text { Gas- } \\
\text { permeable } \\
\text { polymer }\end{array}$ & Polymer & $\begin{array}{lr}\text { Optic } & \text { fiber } \\
\text { detection } & - \\
\text { change } & \text { in } \\
\text { absorbance } & \text { or } \\
\text { reflectance } & \text { of } \\
\text { the film } & \end{array}$ & $2.5 \mathrm{~dB} / \% \mathrm{CO}_{2}$ & $\begin{array}{l}\text { High } \\
\text { relative } \\
\text { humidity } \\
\text { and die } \\
\text { concentrati } \\
\text { on } \\
\text { dependent }\end{array}$ & $100 \%$ & [54] \\
\hline $\begin{array}{l}\text { Electro } \\
\text { chemical - } \\
\text { metal } \\
\text { oxide }\end{array}$ & Oxide & $\begin{array}{l}\text { Electrical } \\
\text { characteristics } \\
\text { measurements - } \\
\text { conductance } \\
\text { and resistance } \\
\text { change due to } \\
\text { transfer of } \\
\text { electrons }\end{array}$ & - & $\begin{array}{l}\text { Temperatur } \\
\text { e dependent }\end{array}$ & $100 \%$ & [49] \\
\hline
\end{tabular}




\begin{tabular}{|c|c|c|c|c|c|c|}
\hline $\begin{array}{l}\text { Polypyrrol } \\
\text { e }\end{array}$ & $\begin{array}{l}\text { Synthetic } \\
\text { polymer }\end{array}$ & $\begin{array}{l}\text { A } \\
\text { potentiometric } \\
\text { probe made of } \\
\text { bicarbonate- } \\
\text { doped } \\
\text { polypyrrole } \\
\text { membrane as } \\
\text { the pH-sensing } \\
\text { device detects } \\
\text { the changes in } \\
\text { concentration of } \\
\text { the gas }\end{array}$ & $\begin{array}{l}-50.69 \\
\mathrm{mV} / \mathrm{dec}\end{array}$ & $\begin{array}{l}\text { Bicarbonate } \\
\text { solution } \\
\text { dependent }\end{array}$ & $\begin{array}{l}10000 \\
\text { ppm }\end{array}$ & [44] \\
\hline $\begin{array}{l}\text { Polyvinyl } \\
\text { alcohol } \\
\text { and } \\
\text { polyanilin } \\
\text { e } \\
\text { anthranalic } \\
\text { acid }\end{array}$ & $\begin{array}{l}\text { Synthetic } \\
\text { polymer }\end{array}$ & $\begin{array}{l}\text { Operating under } \\
\text { high humidity. } \\
\text { Change in } \\
\text { electrical } \\
\text { conductivity }\end{array}$ & $\begin{array}{l}5.069 \times 10^{3} \\
\Omega / \mathrm{ppm}\end{array}$ & $\begin{array}{l}\text { High } \\
\text { relative } \\
\text { humidity } \\
\text { dependent }\end{array}$ & $\begin{array}{l}\mathrm{CO}_{2} \\
\text { range: } \\
3 \times 10^{2} \\
- \\
1.5 \times 10^{5} \\
\text { ppm }\end{array}$ & [47] \\
\hline
\end{tabular}




\section{Conclusion}

The present work gives an overview of the potential use of wheat gluten as a carbon dioxide sensor, particularly at high relative humidity values $(90 \% \mathrm{RH})$. These experiments have been performed with a strict control of the relative humidity (20\% and $90 \% \mathrm{RH})$ and temperature $\left(25^{\circ} \mathrm{C}\right)$, as the variation of the aforementioned factors would obscure the effects of carbon dioxide on the dielectric properties of wheat gluten. It has been demonstrated that the dielectric permittivity and loss increased from $7.81 \pm 0.07$ to $12.02 \pm 0.03$ and from $0.51 \pm 0.01$ to $1.09 \pm 0.02$ respectively with carbon dioxide concentration. The process is not reversible as the permittivity and dielectric loss shifted back to $9.42 \pm 0.03$ and $0.68 \pm 0.01$ respectively which are not the initial values. This indicates that the protein structure was modified. The irreversibility and hysteresis were even more pronounced with increasing cycles of carbon dioxide treatment. Water, so far, is an essential element for the sorption of carbon dioxide in the protein network as the dielectric constants were modified only at $90 \%$ of relative humidity. Further studies are still required for the evaluation of the full potential of using wheat gluten as carbon dioxide sensor.

\section{Funding sources}

Agence National de la Recherche (ANR) was the funding source.

\section{Acknowledgement}

Authors thank the "Agence Nationale de la Recherche" (a French funding agency) for funding this study within the framework of NextGenPack project. Special thanks are given to "l'Institut d'Electronique et des Systèmes" Montpellier for providing the necessary equipments for the smooth progress of the study. Carole Guillaume is an Associate Professor in Food Chemistry 
at the University of Montpellier 2. She received her Master Degree in Agroresources Sciences from "Ecole Nationale Supérieure Agronomique" (ENSAT) in Toulouse, and received her PhD from the University of Montpellier 2 based on the Dynamic study of rennet induced gelation of milk subjected to $\mathrm{CO}_{2}$ pressure. Her research interests are respiring products requirements for packaging, multiscale structuring of agro-based materials in relation with their mass transfer properties, and development of decision support tools for food packaging dimensioning.

Brice Sorli was born in Montpellier, France, in 1972. He received the M.S degree in Electrical Engineering and Ph.D degree from Montpellier University in 1998 and 2001, respectively. During this period, he worked on electronic measurements, instrumentation, thermal analysis and humidity sensors. In 2002, he joined the "Laboratoire d'Electronique et de Nanotechnologies Capteurs" Claude Bernard University, Lyon, where he has been involved in the design and implementation of nuclear magnetic resonance micro-probe for " Labs on chip " and in vivo applications. In 2005, he joined IES Lab, Montpellier University, and he works on sensors and RFID applications.

Nathalie Gontard is a Research Director in Food, packaging and materials sciences. She received her Engineer and Master diplomas in Food Science and Process engineering from the University of Montpellier (France) in 1988 and received her PhD thesis in Material and Food Science from the University of Montpellier (France). She has the Title for Research Activities Direction (HDR) in Process Engineering and Food Science: material science applied to polymers from agricultural origins in 1998. Her research topics of interest are on the Structure/mass transfer relationship and modeling in biocomposites, on Integrated approach of food packaging systems, on Environmental impact and ecodesign of bio-materials, and on Safety and nano-materials and technologies.

FEM, finite element method; IDC, interdigital capacitor; RC, resistance capacitance; $\mathrm{RH}$, relative humidity; RFID, radio frequency identification; VNA, vector network analyzer; WG, wheat gluten; d.b, dry basis; UHF, ultra high frequency; DVS, dynamic vapor sorption; VNA, vector network analyzer; $\mathrm{CO}_{2}$, carbon dioxide. 


\section{References}

[1] C. Guillaume, D. Guehi, N. Gontard, E. Gastaldi, Gas transfer properties of wheat gluten coated paper adapted to eMAP of fresh parsley, J. Food Eng. 119 (2013) 362-369. doi:10.1016/j.jfoodeng.2013.06.008.

[2] N. Gontard, R. Thibault, B. Cuq, S. Guilbert, J.F. Breton, Influence of Relative Humidity and Film Composition on Oxygen and Carbon Dioxide Permeabilities of Edible Films, J. Agric. Food Chem. (1996) 1064-1069.

[3] K.L. Yam, T.P. T., J. Miltz, Intelligent Packaging: Concepts and Applications, J. Food Sci. 70 (2005) 37-43.

[4] N. Gontard, R. Thibault, B. Cuq, S. Guilbert, Influence of relative humidity and film composition on oxygen and carbon dioxide permeabilities of edible films, J. Agric. Food Chem. 44 (1996) 1064-1069. doi:10.1021/jf9504327.

[5] I.S. Arvanitoyannis, A.C. Stratakos, Application of Modified Atmosphere Packaging and Active/Smart Technologies to Red Meat and Poultry: A Review, Food Bioprocess Technol. 5 (2012) 1423-1446. doi:10.1007/s11947-012-0803-z.

[6] M. Sivertsvik, J.T. Rosnes, H. Bergslien, Modified atmosphere packaging. In minimal processing technologies in the food industry, Woodhead Publishing Ltd, 2002.

[7] M. Gällstedt, A. Brottmon, M.S. Hedenqvist, Packaging-related properties of proteinand chitosan-coated paper, Packag. Technol. Sci. 18 (2005) 161-170. doi: $10.1002 /$ pts. 685 .

[8] E. Gastaldi, P. Chalier, a. Guillemin, N. Gontard, Microstructure of protein-coated paper as affected by physico-chemical properties of coating solutions, Colloids Surfaces A Physicochem. Eng. Asp. 301 (2007) 301-310. doi:10.1016/j.colsurfa.2006.12.079.

[9] C. Guillaume, J. Pinte, N. Gontard, E. Gastaldi, Wheat gluten-coated papers for biobased food packaging: Structure, surface and transfer properties, Food Res. Int. 43 (2010) 1395-1401. doi:10.1016/j.foodres.2010.04.014.

[10] C. Guillaume, I. Schwab, E. Gastaldi, N. Gontard, Biobased packaging for improving preservation of fresh common mushrooms (Agaricus bisporus L.), Innov. Food Sci. Emerg. Technol. 11 (2010) 690-696. doi:10.1016/j.ifset.2010.05.007.

[11] C. Barron, P. Varoquaux, S. Guilbert, N. Gontard, B. Gouble, Modified atmosphere packaging of cultivated mushroom (Agaricus bisporus L .) with hydrophilic films, J. Food Sci. 66 (2001) 251-255. doi:10.1111/j.1365-2621.2002.tb11393.x.

[12] L.C. Haynes, J.P. Locke, Microwave Permittivities of Cracker Dough, Starch and Gluten, J. Microw. Power Electromagn. Energy. 30 (1995) 124-131. 
[13] M.S. Venkatesh, G.S.V. Raghavan, An Overview of Microwave Processing and Dielectric Properties of Agri-food Materials, Biosyst. Eng. 88 (2004) 1-18. doi:10.1016/j.biosystemseng.2004.01.007.

[14] B. Ghanbarzadeh, H. Almasi, Biodegradable Polymers, Biodegrad. - Life Sci. (2013) 141 - 145. doi: 10.5772/56230.

[15] B. Lagrain, B. Goderis, K. Brijs, J. a Delcour, Molecular basis of processing wheat gluten toward biobased materials., Biomacromolecules. 11 (2010) 533-41. doi:10.1021/bm100008p.

[16] P.S. Belton, On the Elasticity of Wheat Gluten, J. Cereal Sci. 29 (1999) 103-107. doi:10.1006/jcrs.1998.0227.

[17] B. Lagrain, B.G. Thewissen, K. Brijs, J. a. Delcour, Mechanism of gliadin-glutenin cross-linking during hydrothermal treatment, Food Chem. 107 (2008) 753-760. doi:10.1016/j.foodchem.2007.08.082.

[18] P.R. Shewry, a. S. Tatham, Disulphide Bonds in Wheat Gluten Proteins, J. Cereal Sci. 25 (1997) 207-227. doi:10.1006/jcrs.1996.0100.

[19] H. Wieser, Chemistry of gluten proteins, Food Microbiol. 24 (2007) 115-119. doi:10.1016/j.fm.2006.07.004.

[20] J. Ahmed, H.S. Ramaswamy, V.G.S. Raghavan, Dynamic viscoelastic, calorimetric and dielectric characteristics of wheat protein isolates, J. Cereal Sci. 47 (2008) 417-428. doi:10.1016/j.jcs.2007.05.013.

[21] V. Huang, F. Mclntyre, L. Haynes, H. Levine, L. Slade, Glass transitions in starch, gluten, and bread as measured by TMA, TSC, and dielectric spectroscopy methods, J. Therm. Anal. 47 (1996) 1289-1298.

[22] A. Almutawah, S. a Barker, P.S. Belton, Hydration of gluten: a dielectric, calorimetric, and fourier transform infrared study., Biomacromolecules. 8 (2007) 1601-6. doi:10.1021/bm061206g.

[23] F. Bibi, C. Guillaume, B. Sorli, N. Gontard, Plant polymer as sensing material: Exploring environmental sensitivity of dielectric properties using interdigital capacitors at ultra high frequency, Sensors Actuators B Chem. (2016). doi:10.1016/j.snb.2016.02.021.

[24] A. Striolo, A. Fa, N. El, A. Bertucco, V. Di, Evidence of conformational changes for protein films exposed to high-pressure CO 2 by FT-IR spectroscopy, 27 (2003) 283-295.

[25] T. Cagnon, C. Guillaume, V. Guillard, N. Gontard, Nanostructuring and Microstructuring of Materials from a Single Agropolymer for Sustainable MAP Preservation of Fresh Food, Packag. Technol. Sci. 26 (2013) 137-148. doi:10.1002/pts.1973. 
[26] H. Mujica-Paz, N. Gontard, Oxygen and Carbon Dioxide Permeability of Wheat Gluten Film : Effect of Relative Humidity and Temperature, J. Agric. Food Chem. 80 (1997) 4101-4105.

[27] C. Pochat-Bohatier, J. Sanchez, N. Gontard, Influence of relative humidity on carbon dioxide sorption in wheat gluten films, J. Food Eng. 77 (2006) 983-991. doi:10.1016/j.jfoodeng.2005.08.026.

[28] S. Stegmeier, M. Fleischer, a. Tawil, P. Hauptmann, K. Egly, K. Rose, Mechanism of the interaction of $\mathrm{CO} 2$ and humidity with primary amino group systems for room temperature CO2 sensors, Procedia Chem. 1 (2009) 236-239. doi:10.1016/j.proche.2009.07.059.

[29] H.E. Endres, R. Hartinger, M. Schwaiger, G. Gmelch, M. Roth, Capacitive CO2 sensor system with suppression of the humidity interference, Sensors Actuators, B Chem. 57 (1999) 83-87. doi:10.1016/S0925-4005(99)00060-X.

[30] F. Bibi, C. Guillaume, B. Sorli, N. Gontard, Plant polymer as sensing material: Exploring environmental sensitivity of dielectric properties using interdigital capacitors at ultra high frequency, Sensors Actuators, B Chem. 230 (2016). doi:10.1016/j.snb.2016.02.021.

[31] T. Cagnon, Transferts dans les systèmes emballage/Aliments: Structuration à façon de matériaux multicouches pour l'emballage sous atmosphère modifiée., 2012.

[32] A. Gennadios, Protein-based films and coatings, Aristippos, 2002.

[33] B.M. Lacquet, P.L. Swart, A new electrical circuit model for porous dielectric humidity sensors, Sensors Actuators B Chem. 17 (1993) 41-46. doi:10.1016/09254005(93)85182-A.

[34] E.C. Dickey, O.K. Varghese, K.G. Ong, D. Gong, M. Paulose, C. a Grimes, Highly Ordered Nanoporous Alumina Films, Sensors. 2 (2002) 91-110. doi:10.3390/s20300091.

[35] N. Gontard, S. Guilbert, J.L. Cuq, Water and glycerol as plasticizers affect mechanical and water vapor barrier properties of an edible wheat gluten film, J. Food Sci. 58 (1993) 206-211. doi:10.1111/j.1365-2621.1993.tb03246.x.

[36] N. Gontard, S. Ring, Edible Wheat Gluten Film: Influence of Water Content on Glass Transition Temperature, J. Agric. Food Chem. 44 (1996) 3474-3478. doi:10.1021/jf960230q.

[37] M. Pouplin, a. Redl, N. Gontard, Glass transition of wheat gluten plasticized with water, glycerol, or sorbitol, J. Agric. Food Chem. 47 (1999) 538-543. doi:10.1021/jf980697w.

[38] M. Imtiaz-Ul-Islam, L. Hong, T. Langrish, CO2 capture using whey protein isolate, Chem. Eng. J. 171 (2011) 1069-1081. doi:10.1016/j.cej.2011.05.003. 
[39] E. Chaix, C. Guillaume, V. Guillard, Oxygen and Carbon Dioxide Solubility and Diffusivity in Solid Food Matrices: A Review of Past and Current Knowledge, Compr. Rev. Food Sci. Food Saf. 13 (2014) 261-286. doi:10.1111/1541-4337.12058.

[40] J.A. Daniels, R. Krishnamurthi, S.S.H. Rizvi, A review of effects of carbon dioxide on microbial growth and food quality, J. Food Prot. 48 (1984) 532-537.

[41] G.W. Hofland, A. De Rijke, R. Thiering, L. a M. Van Der Wielen, G.J. Witkamp, Isoelectric precipitation of soybean protein using carbon dioxide as a volatile acid, J. Chromatogr. B Biomed. Sci. Appl. 743 (2000) 357-368. doi:10.1016/S03784347(00)00259-0.

[42] L. Ansaloni, M. Minelli, M. Giacinti Baschetti, G.C. Sarti, Effect of relative Humidity and temperature on gas transport in Matrimid®: Experimental study and modeling, J. Memb. Sci. 471 (2014) 392-401. doi:http://dx.doi.org/10.1016/j.memsci.2014.08.019.

[43] C. Joly, S. Goizet, J.C. Schrotter, J. Sanchez, M. Escoubes, Sol-gel polyimide-silica composite membrane: Gas transport properties, J. Memb. Sci. 130 (1997) 63-74. doi:10.1016/S0376-7388(97)00008-2.

[44] B.J. V Tongol, C. a. Binag, F.B. Sevilla, Surface and electrochemical studies of a carbon dioxide probe based on conducting polypyrrole, Sensors Actuators, B Chem. 93 (2003) 187-196. doi:10.1016/S0925-4005(03)00180-1.

[45] H.S. Hong, J.W. Kim, S.J. Jung, C.O. Park, Thick film planar CO2 sensors based on Na $\beta$-alumina solid electrolyte, J. Electroceramics. 15 (2005) 151-157. doi:10.1007/s10832005-2192-4.

[46] A.R. Varlan, W. Sansen, Micromachined conductometric p ( CO 2 ) sensor, 44 (1997) 309-315.

[47] T. Oho, T. Tonosaki, K. Isomura, K. Ogura, A CO2 sensor operating under high humidity, J. Electroanal. Chem. 522 (2002) 173-178. doi:10.1016/S00220728(02)00712-X.

[48] P. Puligundla, J. Jung, S. Ko, Carbon dioxide sensors for intelligent food packaging applications, Food Control. 25 (2012) 328-333. doi:10.1016/j.foodcont.2011.10.043.

[49] S. Neethirajan, D.S. Jayas, S. Sadistap, Carbon dioxide (CO2) sensors for the agri-food industry-A review, Food Bioprocess Technol. 2 (2009) 115-121. doi:10.1007/s11947008-0154-y.

[50] A. Oprea, N. Bârsan, U. Weimar, M.L. Bauersfeld, D. Ebling, J. Wöllenstein, Capacitive humidity sensors on flexible RFID labels, Sensors Actuators B. 132 (2007) 2039-2042. doi:10.1109/SENSOR.2007.4300564. 
[51] R.A. Potyrailo, C. Surman, N. Nagraj, A. Burns, Materials and Transducers Toward Selective Wireless Gas Sensing, Chem. Rev. 111 (2011) 7315-7354. doi:10.1021/cr2000477.

[52] J. Shin, P. V. Braun, W. Lee, Fast response photonic crystal $\mathrm{pH}$ sensor based on templated photo-polymerized hydrogel inverse opal, Sensors Actuators, B Chem. 150 (2010) 183-190. doi:10.1016/j.snb.2010.07.018.

[53] F. Colin, T.J.N. Carter, J.D. Wright, Modification of a piezo-optical gas dosimeter system towards continuous gas sensing: A feasibility study with carbon dioxide, Sensors Actuators, B Chem. 90 (2003) 216-221. doi:10.1016/S0925-4005(03)00031-5.

[54] N. Nakamura, Y. Amao, An optical sensor for CO2 using thymol blue and europium(III) complex composite film, Sensors Actuators, B Chem. 92 (2003) 98-101. doi:10.1016/S0925-4005(03)00098-4.

[55] H. Segawa, E. Ohnishi, Y. Arai, K. Yoshida, Sensitivity of fiber-optic carbon dioxide sensors utilizing indicator dye, Sensors Actuators, B Chem. 94 (2003) 276-281. doi:10.1016/S0925-4005(03)00372-1. 
Fabien Bibi received a Master Degree in Sensors and Associated Systems from the University of Montpellier (France) in 2012 and received his PhD at "I'Institut National de la Recherche Agronomique" (INRA) SupAgro in Montpellier, France in 2015. His PhD was entitled: Study of dielectric properties of vegetal proteins at high frequency for the development of green RFID bio-sensors to be interfaced with passive UHF RFID systems. His main research interests are in the development of capacitive and resistive sensors, to be coupled to RFID tags for intelligent packaging and food chain monitoring.

Carole Guillaume is an Associate Professor in Food Chemistry at the University of Montpellier 2. She received her Master Degree in Agroresources Sciences from "Ecole Nationale Supérieure Agronomique" (ENSAT) in Toulouse, and received her PhD from the University of Montpellier 2 based on the Dynamic study of rennet induced gelation of milk subjected to $\mathrm{CO}_{2}$ pressure. Her research interests are respiring products requirements for packaging, multiscale structuring of agro-based materials in relation with their mass transfer properties, and development of decision support tools for food packaging dimensioning.

Brice Sorli was born in Montpellier, France, in 1972. He received the M.S degree in Electrical Engineering and Ph.D degree from Montpellier University in 1998 and 2001, respectively. During this period, he worked on electronic measurements, instrumentation, thermal analysis and humidity sensors. In 2002, he joined the "Laboratoire d'Electronique et de Nanotechnologies Capteurs" Claude Bernard University, Lyon, where he has been involved in the design and implementation of nuclear magnetic resonance micro-probe for "Labs on chip " and in vivo applications. In 2005, he joined IES Lab, Montpellier University, and he works on sensors and RFID applications.

Nathalie Gontard is a Research Director in Food, packaging and materials sciences. She received her Engineer and Master diplomas in Food Science and Process engineering from the University of Montpellier (France) in 1988 and received her PhD thesis in Material and Food Science from the University of Montpellier (France). She has the Title for Research Activities Direction (HDR) in Process Engineering and Food Science: material science applied to polymers from agricultural origins in 1998. Her research topics of interest are on the Structure/mass transfer relationship and modeling in biocomposites, on Integrated approach of food packaging systems, on Environmental impact and ecodesign of bio-materials, and on Safety and nano-materials and technologies. 